\title{
Sciendo
}

RURAL SUSTAINABILITY RESEARCH 43(338), 2020

ISSN - 2256-0939

(c) Latvia University of Life Sciences and Technologies, all rights reserved http://www.Ilu.Iv/en/

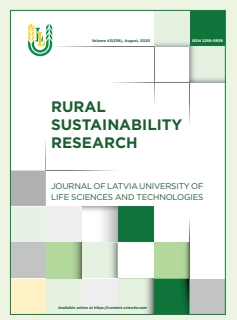

Received: 31 March 2020

Revised: 13 May 2020

Accepted: 11 June 2020

\section{Four-link Spiral Model in the Concept of "Smart Specialization" Innovative Industrial Development}

\author{
*Olga Chernova1, Vladimir Klimuk ${ }^{2}$, Andrejs Lazdins ${ }^{3}$, \\ ${ }^{1}$ Economic Faculty, Southern Federal University, Rostov-on-Don, Russia \\ ${ }^{2}$ Baranovichi State University,Baranovishi, Belarus \\ ${ }^{3}$ Faculty of Economics and Social Development, Latvia University of Life Sciences and Technologies, \\ Jelgava, Latvia \\ ORCID ID: Olga Chernova https://orcid.org/0000-0001-5072-7070 \\ Vladimir Klimuk https://orcid.org/0000-0003-0928-8453
}

JEL code: $\mathrm{O} 31$

\begin{abstract}
One of the mechanisms for enhancing innovative processes in the industry is the application of the concept of the "four-link spiral". In contrast to the 3-link spiral, this model as one of the most important components includes a "society", acting as one of the actors of innovative transformations. Firstly, it is society that is the main consumer of innovative products being created and, thereby, establishes "requirements", forming demands for the quality and parameters of future products; secondly, society, in turn, acts as the initiator and generator of innovations, forming the so-called "social capital" necessary for the implementation of directly innovative transformations. In this scientific work, the problems of the formation of a "smart specialization" strategy for the innovative development of the industrial sector of the national economic system based on the application of the four-link spiral concept are investigated. A system of quantitative indicators for assessing the innovative level of industrial development is presented. The experience of introducing the concept of a fourlink spiral as a mechanism of innovative development of industry (on the example of the Republic of Belarus and the Russian Federation) is given. The aim of the article is to describe innovation processes in the Russian Federation and the Republic of Belarus and to develop an innovation transfer model.

Key words: industrial policy, four-link spiral model, smart specialization strategy, innovative development.
\end{abstract}

\section{Introduction}

Modern problems of regional development are inextricably linked with the solution of the tasks of stimulating innovative processes in the industrial sector in order to build up competitive advantages and conquer new market. In the Commonwealth of Independent States (CIS) countries, in the Republic of Belarus and the Russian Federation, universities are the main generator of innovation, in contrast to the developed countries of the world, where these functions are performed by large corporations. The most important problem in the process of creating innovation is the low level of commercialization of scientific ideas. The main challenge of most national economies, including the Russian Federation and the Republic of Belarus, is the need to harmonize the interactions of individual subjects of innovation systems in the regions.

\section{Methods}

The aim of the article is to describe innovation processes in the Russian Federation and the Republic of Belarus and to develop an innovation transfer model. Main tasks: to describe the theoretical achievements of innovation processes in cooperation between science and enterprises; to develop a knowledge transfer model from science to production. The research used situation analysis method, statistical data analysis method, modelling and monographic method.

\footnotetext{
* Corresponding Author's email: oachernova@sfedu.ru
} 


\section{Results and Discussion}

A study of the problems of the effectiveness of relationships in the vector of scientific and industrial cooperation, involving business, and the state is presented in a number of scientific works of domestic and foreign scientists Anisytsina N.N., Grigorudis E., Ickovic G., Kallas M.S., Karayanis E., Klimuk V.V., Lazdins A., Kuznetsova E.B., Leidesdorf L., Matviiva L.G., Midtkandala I., Neborsky E.V., Chernova OA., Jaseva G.A. and others.

In the CIS countries, so far, the theory and practice of innovation policy of national economic systems has not found effective mechanisms for the translation and commercialization of scientific developments. At the same time, one should be soberly aware that a cardinal innovative breakthrough is possible only in those sectors and fields of activity that have sufficient potential for this, which corresponds to the principles of specialization. However, specialization should be "smart" (Carayannis \& Grigoroudis, 2016), i.e. take into account the intellectual component (knowledge base) of the industrial growth points of the corresponding region. The concept of "smart specialization" involves identifying the competitive advantages of the region (in this study, in the industry) and identifying the main intellectual transformations and decisions required for the industrial development of the region. This process should be carried out as a collective exchange of knowledge between four regional subsystems: the education system, the economic, political system and civil society - forming a four-link spiral model (Figure 1).
Isolation of these subsystems into a system-forming mechanism for activating innovative processes has allowed a number of foreign researchers to develop a triple helix model and formulate the concept of a 4-link interaction spiral, which will form the basis of this study.

To achieve efficiency from interaction, it is important to consider the specifics of territorial factors and a set of conditions, the resource potential of the region. That does not allow to develop a single, universal mechanism for the implementation of the presented model.

Modern national socio-economic systems are characterized by constant adjustment of development vectors and paths. This is connected with:

- the emergence of new participants in innovation processes;

- new global challenges;

- the advent of new technologies;

- the state of the domestic market;

- resource potential etc.

This adjustment is reflected in the consistent transformation of the priorities of industrial policy with a gradual shift in emphasis from the extensiveness of innovative processes to their intensification, where the main factor in the development is "knowledge". Table 1 presents the phased evolution of innovation priorities in Russia and Belarus (based on messages from the Heads of State to the government).

The declared priorities of the countries (Table 1) allow us to trace how the tasks of developing market mechanisms, the innovation infrastructure of

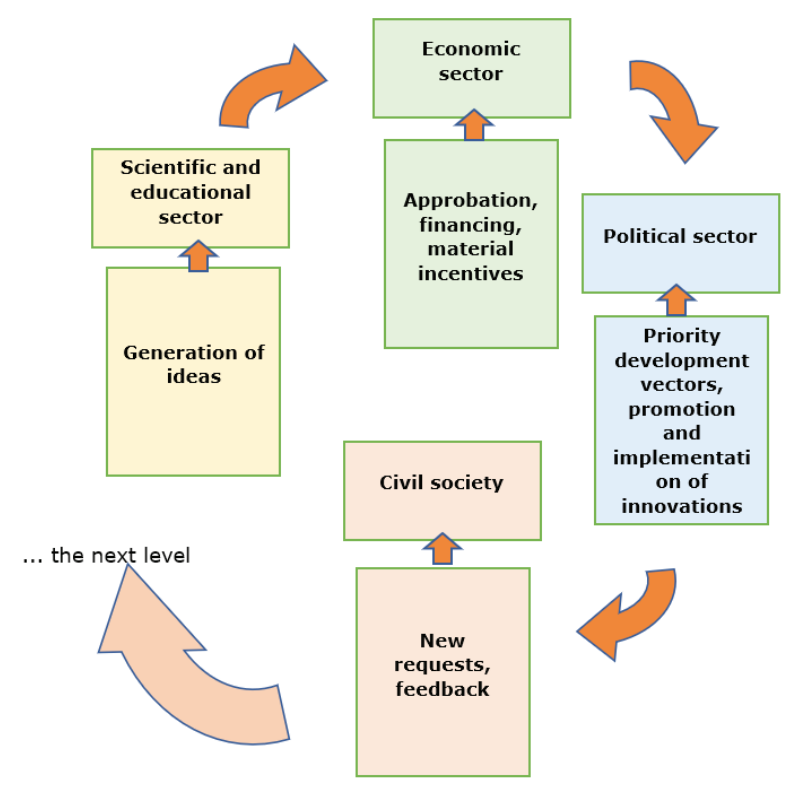

Source: construction based on the authors'study.

Figure 1. Interaction of components in a 4-link spiral model. 
The evolution of innovation priorities in Russia Federation and Republic of Belarus for 2007-2018

\begin{tabular}{|c|c|}
\hline $\begin{array}{l}\text { Priorities for the innovative development of the } \\
\text { Russian Federation }\end{array}$ & $\begin{array}{l}\text { Priorities of innovative development of the Republic } \\
\text { of Belarus }\end{array}$ \\
\hline \multicolumn{2}{|r|}{$2007-2008$} \\
\hline $\begin{array}{l}\text { - Energy security } \\
\text { - Entrepreneurship and private initiative } \\
\text { development }\end{array}$ & $\begin{array}{l}\text { - Eliminating infrastructure limitations of growth } \\
\text { - More efficient use of natural resources } \\
\text { - The development of high-tech industrial } \\
\text { production }\end{array}$ \\
\hline \multicolumn{2}{|c|}{ 2009-2010 } \\
\hline $\begin{array}{l}\text { - Development of a new technological strategy, } \\
\text { business strategy, transit strategy } \\
\text { - Development of alternative energy sources } \\
\text { - Informatization strategy }\end{array}$ & $\begin{array}{l}\text { - Implementation of the 4I concept: institutions, } \\
\text { investments, innovations, intelligence } \\
\text { - Revival of the educational system }\end{array}$ \\
\hline \multicolumn{2}{|c|}{ 2011-2014 } \\
\hline $\begin{array}{l}\text { - Development of cooperation between } \\
\text { institutions and enterprises } \\
\text { - Import substitution in the economy } \\
\text { - Development of the knowledge economy, } \\
\text { development of human capital } \\
\text { - Informatization of society }\end{array}$ & $\begin{array}{l}\text { - Joint research activities of universities and } \\
\text { industrial companies } \\
\text { - Improving the energy efficiency }\end{array}$ \\
\hline \multicolumn{2}{|c|}{$2015-2016$} \\
\hline $\begin{array}{l}\text { - The efficiency of use of budgetary funds } \\
\text { - Antitrust and competition policy } \\
\text { - Financial market development, raising capital }\end{array}$ & $\begin{array}{l}\text { - The development of international cooperation } \\
\text { - Innovative import substitution } \\
\text { - The interaction of the state and business, } \\
\text { industry and universities }\end{array}$ \\
\hline \multicolumn{2}{|r|}{2017} \\
\hline $\begin{array}{l}\text { - Export growth } \\
\text { - Implementation of information technology } \\
\text { - Education system development }\end{array}$ & $\begin{array}{l}\text { - Development of human capital } \\
\text { - Increased investment in high-tech manufacturing } \\
\text { - Export growth } \\
\text { - Digital Economy Development }\end{array}$ \\
\hline \multicolumn{2}{|c|}{2018} \\
\hline $\begin{array}{l}\text { - Increasing innovation activity in the actual } \\
\text { economic sector } \\
\text { - Creating high-performance Jobs } \\
\text { - Export growth }\end{array}$ & $\begin{array}{l}\text { - Technological development } \\
\text { - Favourable environment for start-ups } \\
\text { - Development of resource decoupling technology } \\
\text { and energy sectors } \\
\text { - The international cooperation }\end{array}$ \\
\hline
\end{tabular}

Source: author's calculations.

international cooperation is gradually evolving in the context of a transition to a knowledge economy and post-industrial production. The most characteristic feature of this process is the gradual decrease in the dominant role of the state in innovative development and the involvement of new actors in modernization transformations - a new model of innovative processes is formed within the "triple helix" with the change of the leading link (state) to scientific and educational organizations.

For most foreign countries, the main initiator of research is large corporations, for example, Lenovo, Huawei, Gilead.
In the "triple helix model" of innovative development, each of its participants (universities, business, and government) provides a system to produce certain knowledge. As a result, knowledge is gradually moving into the category of strategic resource. New forms of processes for their creation, use and distribution are emerging. As a result, a model of "knowledge of the third kind" is formed - that knowledge that allows you to rethink the ways and means of production and economic activity. They are used to form competitive advantages.

Existing regional development strategies, as a rule, are aimed at building up the economic potential 


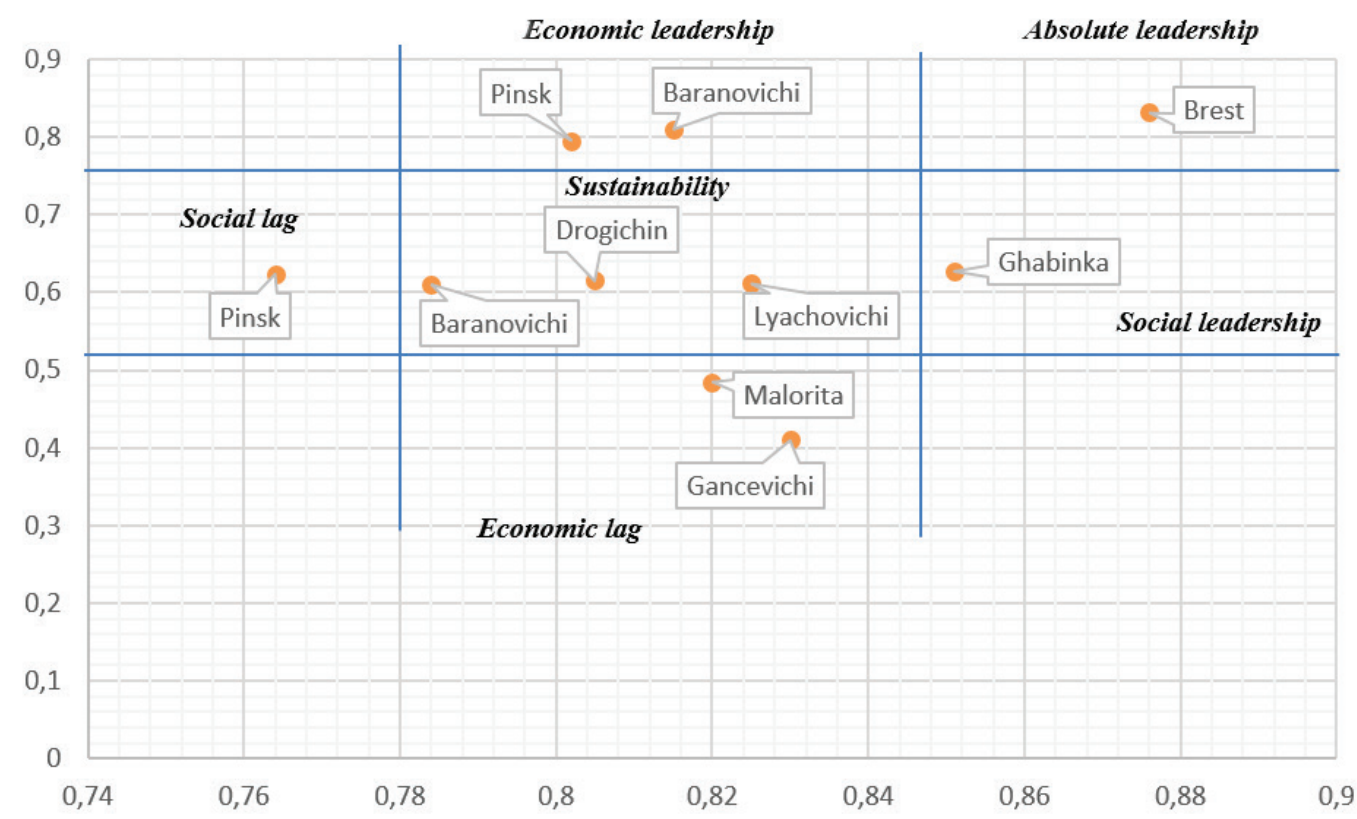

Source: author's calculations based on National Statistical Committee of the Republic of Belarus (2019).

Figure 2. The matrix "Regional socio-economic development" (on the example of the Brest region of the Republic of Belarus).

of the territory through the creation of innovations in any form and in all areas of activity. However, in most cases this approach seems to be ineffective. The specifics of regional competencies, territorial features, and the level of regional demand for products of local industrial production, existing interregional and international relations lead to significant differences in the economic and social characteristics of individual regional markets of the country. This fact makes it necessary to develop a development strategy that would not copy the positive experience of other regions but was initially formed on the basis of its own unique advantages and existing potential, that is, had its own industrial specialization. An effective industrial development strategy for the regional economy, in addition to industrial specialization, should be aimed at "smart" economic growth, which, in accordance with the definition of the European Union (Europe 2020, 2010), means an "innovation strategy" that sets priorities aimed at gaining competitive advantages by development of our own scientific and innovative potential in accordance with the needs of the business in order to take full advantage of emerging opportunities and trends market, while avoiding duplication and fragmentation of efforts.

The implementation of the strategy of "smart specialization" means the organization of effective interaction of the following systems:

- educational systems that shape human capital;

- the system of the economy that forms economic capital;
- public administration systems, which determine, among other things, the institutional environment for interaction;

- a system of civil society forming social and information capital.

The core of the four-link spiral model is consumers of innovation (Carayannis \& Grigoroudis, 2016). Thus, this model directs the innovation process to the creation of products that have a certain value for users. In other words, innovations should be "useful", and the degree of usefulness of the produced innovations should be a criterion for assessing the effectiveness of the implementation of industrial policy in the region.

To analyse socio-economic regional specialization, the methodology of dynamic and equity indicators (Klimuk \& Lazdins, 2019) based on the calculation of integrated regional development indices using a set of 18 indicators. The results of the analysis are presented in the form of a regional development matrix (Figure 2).

Based on the resource components, the values of the integral resource efficiency levels of the regions of the Republic of Belarus were calculated (Figure 3 ).

The presented calculations reflect the non-use of the intellectual potential acting as the driving force (the "knowledge base") of the innovative transformation of the national economic system, the industrial sector. This finding makes it necessary to develop effective mechanisms to stimulate the generation of innovations, their testing and implementation in the 


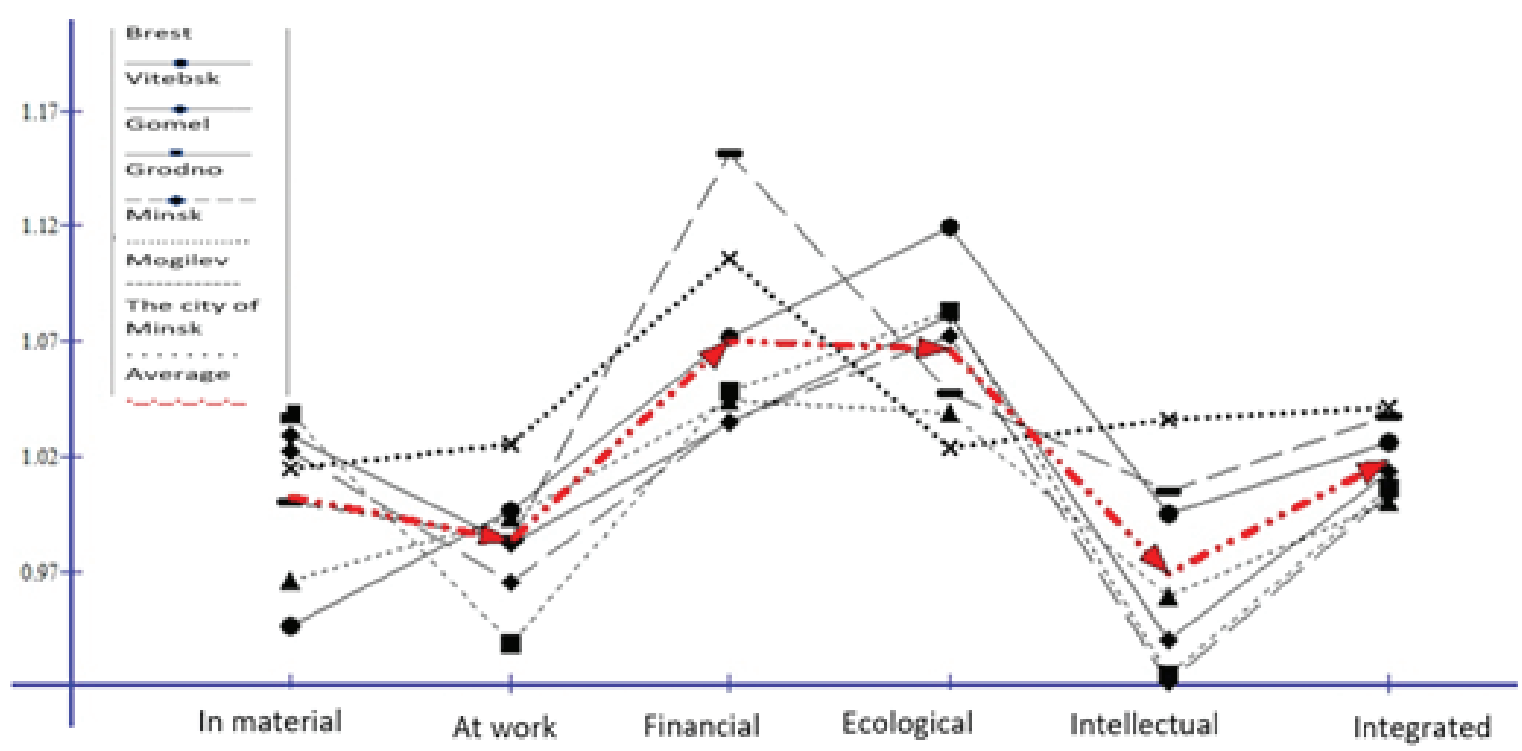

Source: author's calculations based on National Statistical Committee of the Republic of Belarus.

Figure 3. Dynamics of private and integral levels of resource efficiency of the regions of the Republic of Belarus for 2005-2015.

real sector of the economy with the aim of increasing the competitiveness of regions and countries.

To analyse the processes of innovative industrial development in Russia and Belarus in terms of determining the degree of usefulness of innovation "smart development" - it is proposed to use the following indicators:

- the rate of change in the proportion of innovative products in the total volume of industrial products;

- the rate of change in the volume of production of innovative industrial products.

- the rate of change in investment in industries;

- the rate of change in the proportion of workers performing research and implementing development in the industrial sector in the total number of people employed in industry;

- the rate of change in the volume of production of products of V, VI technological orders in industry;

- the ratio of the rate of change in the volume of production of innovative industrial products to the rate of change in GDP;

- the ratio of the rate of change in the volume of export of innovative industrial products to the rate of change in the volume of import of these products.

The use of indicators of growth rates is conscious and due to the goal - to determine the dynamics of innovative processes, providing the possibility of subsequent generalization of indicators in a single integrated value. At the same time, it seems important to highlight the high-tech sector of the economy to assess the level of development of the knowledgebased economy.

The calculated values of the presented indicators are reflected in the Table. 2. Moreover, to obtain a generalized picture of the state of the processes of introducing innovations into the industry of the economies of these countries, an integral indicator is used, defined as the product of the studied rates of change.

The data presented demonstrate that there is a positive trend in the development of innovative processes in the industry of Russia and Belarus. The "bottleneck" of industrial development is the relatively low level of workers employed in scientific research, as well as the continued predominance of import of innovations over export. An important feature is that university employees predominate in the structure of those employed in research and development, while the staff of industrial organizations is poorly represented.

The solution to this problem is seen in the implementation of the four-link spiral model, which involves the establishment and development of integration interactions between science, business, society and the state.

To intensify innovative processes in industry, we will use a four-link spiral model, building on the business incubator structure of Baranavichy State University (BarSU), which since 2018 began actively engaging social resources (communities) in scientific and innovative activities. Within this business incubator, several projects are effectively implemented, including: 


\section{Evaluation indicators of innovative processes in the industry of Russia and Belarus in the concept of "smart specialization"}

\begin{tabular}{|c|l|c|c|c|c|}
\hline \multicolumn{1}{|c|}{$\begin{array}{l}\text { Indicator } \\
\text { Belarus }\end{array}$} & \multicolumn{2}{|c|}{2016} & \multicolumn{2}{c|}{2017} \\
\cline { 2 - 5 } 1. & $\begin{array}{l}\text { The rate of change in the share of innovative products in the total } \\
\text { volume of industrial products. }\end{array}$ & 1.03 & 1.05 & 1.07 & 1.06 \\
\hline 2. & $\begin{array}{l}\text { The rate of change in the volume of production of innovative } \\
\text { industrial products. }\end{array}$ & 1.12 & 1.10 & 1.25 & 1.17 \\
\hline 3. & $\begin{array}{l}\text { The rate of change in the volume of investment in the industrial } \\
\text { sector. }\end{array}$ & 1.03 & 1.01 & 1.05 & 1.02 \\
\hline $\begin{array}{l}\text { The rate of change in the share of employed workers performing } \\
\text { research and implementing development in the industrial sector in } \\
\text { the total number of employees in industry. }\end{array}$ & 0.98 & 1.01 & 1.03 & 102 \\
\hline 5. & $\begin{array}{l}\text { The rate of change in the share of production volume V, VI } \\
\text { technological structures in industry. }\end{array}$ & 1.12 & 1.15 & 1.35 & 1.19 \\
\hline 6. & $\begin{array}{l}\text { The ratio of the rate of change in the volume of production of } \\
\text { innovative industrial products to the rate of change of GDP. }\end{array}$ & 1.05 & 1.08 & 1.12 & 1.11 \\
\hline & $\begin{array}{l}\text { The ratio of the rate of change in the volume of exports of } \\
\text { innovative industrial products to the rate of change in the volume } \\
\text { of imports of these products. }\end{array}$ & 0.95 & 1.01 & 0.98 & 1.01 \\
\hline Integral index & 1.30 & 1.48 & 2.14 & 1.72 \\
\hline
\end{tabular}

Source: author's calculations based on Report - The Role of Smart Specialisation in the EU Enlargement and Neighbourhood Policies.

- business planning of entrepreneurial activity;

- academy of young researchers (industrial creativity);

- psychological workshops for entrepreneurs;

- project management;

- school of information technology to improve information literacy of the population;

- 3D-tours of industrial enterprises of the city etc.
In addition, based on this business incubator, within the framework of the "University 3.0" program implemented in the Republic of Belarus, mechanisms for the commercialization of the results of intellectual activity are developed and tested. So, one of the important aspects of the project implementation is the preliminary work with potential business customers, which is expressed in various forms of the survey, involving the public in scientific and practical events

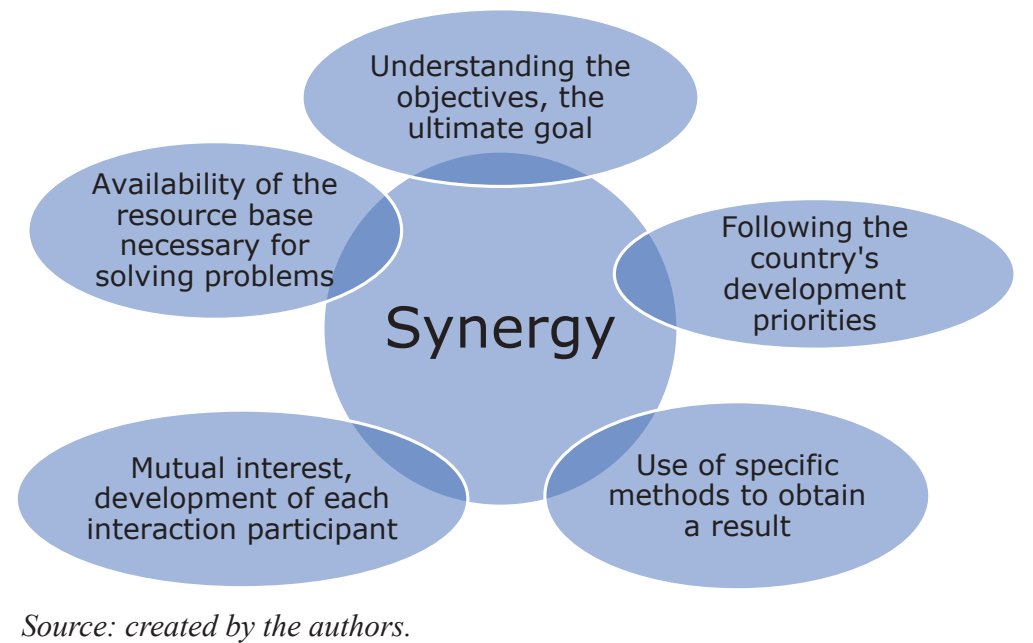

Figure 4. Individual elements of the four-link spiral model of industrial development. 
organized by BarSU, involving the public and business partners in the generation of innovative ideas, determination of the quality parameters of future innovative products. The university interacts with industrial enterprises of the city of various industry specifics (engineering, woodworking, chemical industry, machine tool industry, and retail trade), agriculture, the business sector, financial institutions, and public organizations.

The next stage in the development of the four-link spiral model is the creation of a technology transfer centre that will provide:

- organization of joint research activities of industrial and scientific organizations of the region;

- conducting joint scientific, technical and technological developments;

- the provision of services for the organization of scientific and practical events of innovative subjects;

- consulting services etc.

In general, we can say that Baranovichi State University already implements individual elements of the four-link spiral model of industrial development, creating conditions for obtaining synergistic effects of interaction (Figure 4).

Note that similar models of stimulating innovation processes are used in the USA, Western Europe, for example, at the University of Nyukasel, Cambridge University, Catholic University of Leuven (Belgium), University of Twent (Holland), Plovdiv Technical University (Bulgaria), Sofia Forestry University (Bulgaria) etc.

The experience of these scientific and educational organizations can be used to build a strategy for smart specialization of industrial development within the framework of the four-link spiral concept.

\section{Conclusions, Proposals, Recommendations}

The transition to a knowledge economy necessitates the further development of national innovation systems based on the construction of a four-link spiral model of industrial development. This paradigm suggests that innovation arises as a result of the interaction of science, society, industry and the state. At the same time, the main consumer of innovation is society, which suggests taking its role into account when developing "smart specialization strategies" based on the generation of knowledge as a strategic resource from the region's scientific specifics. Consequently, the directions of further research by the authors are associated with the development of effective organizational and managerial mechanisms for the interactions of the main actors - participants in innovative processes in the industrial sector.

\section{References}

Aniscina, N.N. (2010). Innovaciononni naucnoobrazobatelnii klister kak sposob organizacii innovacionnoi deatelnosti v Vuze/Kreativnoe ekonomika (Innovative research and education cluster as a way of organizing innovation activities at the university/creative economy). No. 4. 2010. Retrieved January 30, 2019 from https://creativeconomy.ru/lib/4133.

Carayannis, E., Grigoroudis, E. (2016). Quadruple Innovation Helix and Smart Specialization: Knowledge Production and National Competitiveness // Foresight and STI Governance. - 2016. - Vol. 10. - № 1. - Pp. 31-42. DOI: 10.17323/1995-459x.2016.1.31.42.

Carayannis, E., Sagi, J. (2001). New vs Old Economy: Insights on Competitiveness in the Global IT industry // Technovation. - Vol. 21. - № 8. - pp. 501-514.

EUROPE 2020. A European strategy for smart, sustainable and inclusive growth. (2010). Retrieved September 9, 2019 from https:// ec.europa.eu/eu2020/pdf/COMPLET\%20 EN\%20BARROSO\%20\%20\%20007\%20-\%20 Europe\%202020\%20-\%20EN\%20version.pdf.

Ickovic, G. (2019). Troinaja spiral. Universiteti predprijatija - gosudarstva. Innovacii v deistvii. (Triple spiral. Universities - enterprises - states. Innovations in action). Retrieved September 10, 2019 from http://old.tusur.ru/export/sites/ ru.tusur.new/ru/innovation/triplehelix/ickovic. pdf.

Jaseva, G. A. (2008). Klasternaja koncepcija innovacionnovo razvitija ekonomiki: obsoznanie i mehanizm realizaciji (Cluster concept of innovative development of the economy: the rationale and mechanism for implementation). Vestnik RUDN. Serija: "Ekonomika” 2008; No. 4, pp. 63-67.

Kallas, M.S. (2011). Vzaimodeistvie nauki, obrozavanija i biznesa kak osnova formirovania innovacionnoi spedi $\mathrm{v}$ Rossii (The interaction of science, education and business as the basis for the formation of the innovation environment in Russia). Vestnik Tomskovo gosudarstvennovo universiteta. Serija: "Ekonomika i prava" 2011; No. 4, (16). p. 186-191.

Karajannis, E., Grigorudis, E. Cetipehzvennaja spiral innovacii i "umnaja specializacija": proizvodstvo znanii i nacionalnaja konkurentosposobnasts // Forsait. T. 10. - №1. - C. 31-42.

Klimuk, V.V., Lazdins, A. (2019). Interaction of Education, Science and Business in Terms of Digital Economy Development. Proceedings of the 2019 International Conference "Economic 
science for rural development". Jelgava, LLU ESAF, 9-10 May 2019, pp. 37-48.

Kuznecov, E. B., Engovatova, A. A. (2016). "Universiteti 4.0": Tocki rosta ekonomiki znanii v Rossii ("Universities 4.0": Points of growth of the knowledge economy in Russia). Innovations 2016; No. 5, (211). pp. 3-9.

Leydesdorff, L. (2012). The Triple Helix, Quadruple Helix, and an N-Tuple of Helices: Explanatory models for analyzing the knowledge-based economy // Journal of the Knowledge Economy. - Vol. 3. - № 1. - pp.25-35.

Matviiva, L. G., Cernova, O. A., Klimuk, V. V. (2015). Ocenka effektivnosti politiki importozametcanija v promislnnasti: metodiceskii instrumentarii (Evaluation of the effectiveness of import substitution policies in industry: methodological tools). №3 (75). C. 3-14.
Midtkandal, I., Sorvik, J. (2012). What is Smart pecialization? // Nordregio News. - № 5. Retrieved September 10, 2019 from http:// www.nordregio.se/en/Metameny/NordregioNews/2012/Smart-Specialisation/Context.

National Statistical Committee of the Republic of Belarus (2019). Retrieved September 10, 2019 from https://www.belstat.gov.by/en/ofitsialnayastatistika/real-sector-of-the-economy/ promyshlennost/current-data $5 /$.

Nevorski, E.V. (2017). Rekonstruirovanie modeli universiteta: perehodkformat4.0(Reconstruction of the university model: transition to the 4.0 format). Retrieved February 28, 2019 from https: //mir-nauki.com/PDF/26PDMN417.pdf.

Silin, J. P., Animica, E. G., Novikova, N. V. (2017). Regionalnie aspekti novoi industrializacii. Ekonomika regiona. - T. 13. - № 3. - C. 684-696. 